\title{
Reform and Innovation of College English Writing Teaching under the Background of Big Data
}

\begin{abstract}
Luo Ni
Shaanxi Technical College of Finance and Economics, Shaanxi, China, 712000

Keywords: big data; College English; writing teaching

Abstract: With the continuous advancement of information technology era in China, various kinds of Internet technology have also begun to be applied to the education industry. Especially at present, China has entered the era of big data, and this era has also brought more impact on College English writing teaching, making the specific writing teaching meet many challenges. This paper first clarifies the basic characteristics of the big data era, and on the basis of explaining the current situation of College English writing teaching in China, and combining with the changes brought about by the big data era to college English writing teaching, it includes three aspects: defining the teaching system based on language application, constructing a relatively perfect evaluation system for writing teaching, and improving the information technology ability of teachers in an all-round way. On the other hand, the reform strategies of College English writing teaching in the era of big data are discussed in detail and comprehensively.
\end{abstract}

With the rapid development of economy, it has entered the era of big data. In the era of big data, there are many characteristics, such as large amount of information and fast transmission speed. At the same time, great changes have taken place in people's thinking and behavior. Therefore, active reform should be carried out in current teaching work, especially in teaching methods, so as to better adapt to the development of the times. Writing teaching plays an important role in College English teaching and plays an important role in improving comprehensive ability. This paper will focus on College English writing teaching in the era of big data.

\section{Advantages of the Big Data Age}

User Identity Has Multidimensional Characteristics

Can Direction People's Decision Making

Has an important influence on people's way of thinking

Figure 1.Advantages of the Big Data Age

As shown in figure 1, the characteristics of large data are analyzed in detail below. 


\subsection{User Identity Has Multidimensional Characteristics}

For the multifaceted characteristics of user identity, it is user-oriented, not only the enjoy of information, but also the main provider of information. Influenced by the Internet, people search for various information in the context of the Internet. In addition, they can also transmit some information in the network. At this time, people are playing the role of information provider.

\subsection{Can Direction People's Decision Making}

In the context of the big data era, people can predict the future direction of things based on information, which greatly improves people's decision-making ability. In some websites, the user's shopping experience will be analyzed, and then the actual preferences of users will be judged. In this way, users can make targeted recommendations in the next shopping, which can not only improve the sales volume of actual products, but also meet the actual needs of users.

\subsection{Has an important influence on people's way of thinking}

In the era of big data, to a great extent, it brings some new things to people, and at the same time, it also transmits information and data to us, and then reforms our thinking mode. With the rapid development of the era of big data, people's own ideology has changed greatly, which can break through the limitations of the traditional sampling method and make great changes in their own way of thinking. Therefore, big data has a great impact on people's way of thinking.

\section{Problems in College English Writing Teaching in China}

As we all know, English writing ability is one of the important indicators to measure a person's English language ability. For a long time, compared with listening and reading in CET-4 and CET-6, English writing has always been a headache module for college students. Because English writing scores account for a large proportion in CET-4 and CET-6, the results of CET-4 and CET-6 are often influenced by the results of the English writing module, but can not be effectively improved. For a long time, the requirement of English writing ability in College English syllabus has been low, which leads to the fact that college English education in China attaches importance to knowledge learning while ignores knowledge output. The form of teaching is "teachers teach mainly, students complete by themselves". The consolidation of classroom knowledge and the process of practice teaching also attach great importance to the absorption and accumulation of existing knowledge. In addition, the teaching of listening and reading in large classes often requires good communication and communication between teachers and students. Therefore, small classes are often used. As shown in Figure 2:

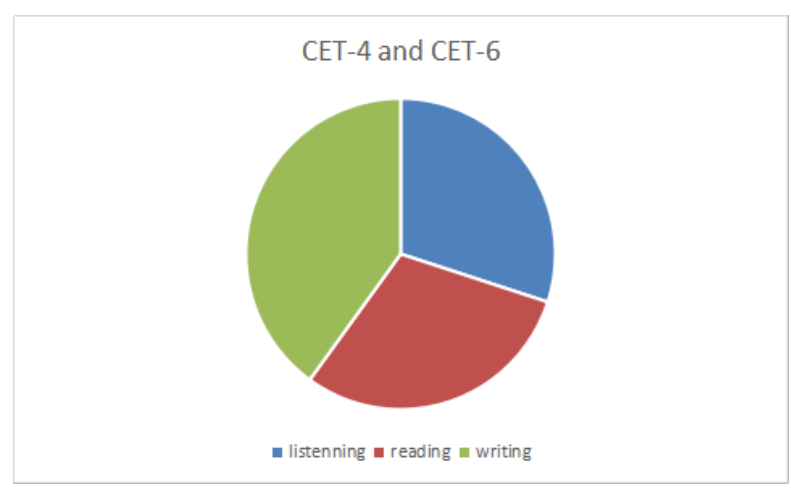

Figure 2.The proportion of dictation, reading and writing in CET 
Generally speaking, limited by educational resources, the number of small classes is between 30 and 50. In a sense, the development of receptiveness and productive skills is not coordinated. At the same time, in the teaching of College English writing in our country, there are still phenomena that teachers are unwilling to teach and students are unwilling to practice. Because most English teachers believe that many English writing skills can not be imparted through teaching in the classroom, but also need to be acquired through repeated practice in specific English language use environment. It should be emphasized that English skills include not only English writing skills, but also English reading, reading, listening and speaking. If students fail to give timely feedback to their teachers on the difficulties they encounter in English language expression, they will also encounter problems in English language expression that will not be solved effectively, which is not conducive to the improvement of studentship writing ability.

\section{The Reform Strategies of College English Writing Teaching in the Four Data Ages}

\subsection{Define the Teaching System Based on Language Application}

For most language teaching, the ultimate goal is language application. In the English teaching system, English writing itself is one of the most important ways of language application, and it also has new changes in the context of the big data era. If teachers can correctly understand the relationship between text, readers and authors in the era of big data, they can fully integrate the advantages of big data to teach. In the era of big data, English text creation has become diversified and can be interpreted from multiple perspectives. In the process of English writing, students are not only the creators of texts, but also the readers of texts. In this case, teachers should also design writing tasks from multiple perspectives. For example, when the task of writing teaching requires students to write a reading report, under the traditional teaching mode, teachers will explain the specific writing method of reading report to students, and designate students to write for a fixed text, and finally teachers will evaluate screenwriting.

But in the era of big data, teachers should adjust when they complete this task. That is to say, let the students choose a text they like, and write the reading report in a way they think is appropriate, and recommend the text they choose to other students. After the students have finished the creation of this paper, the teacher and the students discuss the standard writing of the reading report together, and let the students modify and adjust the standard template. In this process, students can also communicate with each other and revise reading reports together. After completing the revision and adjustment, students can also publish their own written texts to the Internet platform to encourage students to use these texts to communicate with each other. In this way, writing teaching can be well combined with the Internet and big data to improve the final teaching effect.

\subsection{Constructing a relatively perfect writing teaching evaluation system}

In the era of big data, English writing teaching has been unable to leave the support of various information technologies. It is necessary to use Internet information platform in the collection of writing materials, the organization of curriculum activities, the submission and correction of homework, and the online interaction between teachers and students. However, in general, the support of big data technology for the whole English writing teaching should not only stay in these aspects, but also run through the writing teaching evaluation system. According to the current situation of English writing teaching in most colleges and universities in China, most online writing teaching is a relatively independent block mode, and the online platform currently used also pays too much attention to the construction of database and the completion of homework, rarely linked with teaching evaluation. 
In this case, under the background of the big data era, colleges and universities in China should adjust and optimize the online teaching platform currently used, and introduce the evaluation system of English writing teaching, which can comprehensively and comprehensively evaluate the screenwriting situation and the teaching status of different teachers. In this process, colleges and universities should pay attention to the individual differences of different students in English writing. When constructing the evaluation platform, they can integrate these students into the teaching evaluation to ensure that the final teaching evaluation results are suitable for the actual situation of most students and improve their writing level.

\subsection{Enhancing the Information Technology Ability of Teachers in an All-round Way}

In the context of the big data era, the speed of new technology updating is very fast, no one can master all the technologies once and for all. In the English teaching system, big data technology brings more convenience to English writing teaching. Therefore, English teachers should actively master various information-based teaching tools and technologies and integrate them into their own teaching system. It should be noted that teachers should also have the ability to guide students to use new technologies correctly. For example, the popular automatic error correction software will bring more trouble to the teaching of English writing. Many students can not really use these software, but use these software to speculate, or use other channels for plagiarism, which is not conducive to their own writing level.

In this case, teachers should strengthen the norms and corrections of student of Internet and English software. In addition, College English teachers should also recognize their own information literacy deficiencies in the context of the big data era, and actively carry out their own information literacy learning and training. It also requires college English teachers to cooperate with information workers across borders (such as computational linguistics, corpus linguistics, etc.). For College English teachers, it is necessary to seek advice from information technology personnel on the basis of clear teaching rules, and jointly complete the innovation and application of College English writing teaching technology platform under the background of big data era. When the two sides cooperate with each other, the final effect of College English writing teaching can be significantly improved and guaranteed.

\section{Conclusion}

In the era of big data, there are many opportunities for college English teaching, but at the same time, there are also many challenges. Specifically, if college English writing teaching can make full use of all kinds of network resources and new teaching concepts and technologies in the era of big data, then the effectiveness of writing teaching can be better guaranteed. It also requires college English teachers to fully understand the important connotation of big data and the importance of teaching English writing, and to improve studentship language ability and writing level by using big data technology. In this way, the teaching of English writing in Colleges and universities can achieve better changes in the era of big data, complete the established teaching tasks and objectives, and promote the all-round development of students.

\section{References}

[1] Chen Duo. Practice and Exploration of College English Writing Teaching Reform in the Context of Big Data [J]. English Teachers, 2015, 15 (11): 46-48.

[2] Bu Yang ping. On College English Writing Teaching Reform in Higher Vocational Colleges in the Big Data Era [J].Career Space-time, 2016,12(2): 72-74.

[3] Li Tao. Analysis of College English Writing Teaching Reform in the Big Data Era [J]. Electronic Test, 2016 (14): 
79-80.

[4] Wang Fa. Analysis of College English Writing Teaching Reform in the Big Data Era [J]. Journal of Amusing Vocational College, 2017 (2): 211-212.

[5] Tang Jinan, Wu Ian. Application of Writing Automatic Evaluation System in College English Teaching Research [J]. Foreign Language and Foreign Language Teaching, 2012, (4): 56-62. 